\title{
Drivers and dynamics of land use land cover in Ambung VDC of Tehrathum district, Nepal
}

\begin{abstract}
D. Pandey ${ }^{1 *}$, B. P. Heyojoo ${ }^{1}$ and H. Shahi ${ }^{2}$
Land use and land cover change has immense impact on the global environment and ecosystem. Geospatial technologies are very important for monitoring these changes. This research aims to find out the land use land cover dynamics and drivers of Ambung VDC, Tehrathum district. The Landsat images of the year 1990 and 2013 were used for quantifying the changes. Household survey, key informant interview, focus group discussion, training samples collection and direct field observations were carried out to gather socio-economic and bio-physical data. Supervised classification was performed to prepare land cover maps. Change on land use was calculated by using post classification change detection. During 1990-2013, forest cover was found to have increased by $6.6 \%$, agriculture decreased by $5.9 \%$ and others (barren, settlement, grass, rock and water bodies) decreased by $0.7 \%$. The VDC was found to have severe problem of rapid drying of water resources in spite of the increase in forest cover, and so research should be carried out to find out the reason and solve the problem before it is too late.
\end{abstract}

Key words: Forest cover, geographic information system, remote sensing, supervised classification

$\mathrm{L}$ and use and land cover (LULC) dynamics are widespread, accelerating and significant process driven by human action which produces some changes that impact humans (Agarwal et al., 2001). Land cover corresponds to the physical condition of the ground surface, such as forest, grassland, agriculture land and so on while land use reflects human activities like the use of the land for different purposes such as industrial zones, residential zones, and agricultural fields. This definition shows that there is a direct link between land cover and the actions of people in their environment, i.e. land cover change may result from land use (Phong, 2004). Changes in land-use and land cover have impacts on soil and water quality, biodiversity, and global climatic systems and, thus, have important consequences on natural resources (Awasthi et al., 2002).

Remote sensing and geographic information system (RS/GIS) technologies can greatly facilitate the collection, analysis and presentation of resource data (Gautam, 2007). Repeated satellite images and aerial photos are useful for visual assessment of natural resource dynamics occurring at a particular time and space, physical features such as land use, soils, vegetation, stream networks, and landforms at different time scales
(Awasthi, 2004). Satellite images and aerial photos are useful for quantitative evaluation of LULC changes over time (Balla et al., 2007).

There are regional variations in terms of changes in forest conditions, e.g. the forest area in the Terai was found to have decreased with the annual rate of 1.3 percent during 1978/79-1990/91 (DOF, 2005). A recent assessment of forest cover by the Forest Resource Assessment (FRA) Project showed that the Terai forest had decreased by 0.44 percent and 0.40 percent per annum during the periods of 2001-2010 and 1991-2010, respectively (FRA/DFRS, 2014). The FRA findings indicate a declining rate of forest loss in the Terai region in more recent years (MoFSC, 2014). Human intervention in forest environment is generally accepted as the main trigger behind forest conversion (Phong, 2004). Moreover, the mountain region of Nepal is subjected to deforestation and agriculture expansion in the marginal lands (Awasthi et al., 2005). Some programs, such as community forestry have carried out exemplary work on conserving forest resources, but there are also some activities responsible for the dwindling of forest resources in the country (UNEP, 2001). In this context, it is important to understand the status of land use,

\footnotetext{
Institute of Forestry, Pokhara Campus, Nepal, *Email: dpdelite22@gmail.com

${ }^{2}$ District Forest Office, Pyuthan, Nepal
} 
measures undertaken to manage the forests, and programs laid down for the future by the national government. The available land use and forest cover data are both scanty and scattered (UNEP, 2001) most of which is not updated; a very few data have been reported for middle mountain region of Nepal (Awasthi, et al., 2005). Keeping this into consideration, this study was carried out in the Ambung VDC of middle mountain region which lacks studies on the land use dynamics and its driving factors.

\section{Materials and methods}

\section{Study area}

The study was conducted in the Ambung VDC situated in the northern part of Tehrathum District of Koshi Zone of Eastern Nepal (Fig. 1). The VDC lies within the Middle Mountain ecological region, and is at a distance of 3 miles from Myanglung, the district headquarters. It is located between $27^{\circ} 6^{\prime}$ and $27^{\circ} 56^{\prime} \mathrm{N}$ Latitude and between $87^{\circ} 25^{\prime}$ and $87^{\circ} 45 \mathrm{E}$ Longitude. The terrain rises from $600 \mathrm{~m}$ to $2,900 \mathrm{~m}$ above the mean sea level; grassland and pasture are found at the higher altitudes, forests at the middle and settlements at the lower altitudes. The district exhibits subtropical type of climate at the lower altitude to temperate at the higher altitudes with an average temperature of $15^{\circ}-25^{\circ} \mathrm{C}$ and $1,650 \mathrm{~mm}$ annual average rainfall.

This VDC is an important part of biologically very important Tinjure-Milke-Jaljale forest, which is considered as the capital of Rhododendron. The major portion of the VDC is covered by forests with major tree species like Alnus Nepalensis, Schima wallichi, Pinus roxburgii, Pinus wallichiana, Quercus lanata, Quercus floribunda, Castonopsis tribuloides and Rhododendron arboretum.

The total population of the VDC is 3,613 with 1,681 males and 1,932 females; the total households being 790 (CBS, 2012). Majority of the people in the VDC are Limbu followed by Gurung, Magar, Kami, Brahmin, Chhetri and Newar. Most of the people depend upon the integrated system of farming, forests and livestock for their livelihood as in other hilly areas of Nepal. However, in the recent years, especially the younger people are gradually leaving their traditional occupation and are attracted to foreign employment; particularly, Mongolian communities are attracted towards national as well as foreign security services.

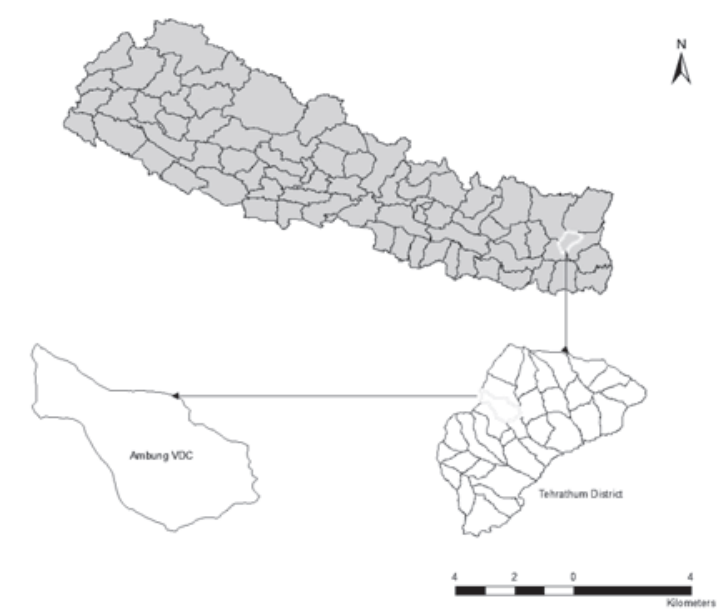

Fig. 1: Map of study area

\section{Data collection}

Both primary as well as secondary data were collected for the purpose of the study. The socioeconomic data and information pertaining to research issues were collected through field observation, household survey, key informant interview and focus group discussions conducted with key persons and different groups of people like community forest user groups (CFUGs), disadvantaged groups and mother groups. Biophysical data, satellite images (Landsat-5 TM of 1990 and Landsat-8 of 2013), topographic map (at the scale 1:25000) of the study area, climatic data and statistical data were collected from other sources such as the Institute of Forestry, the District Forest Office, Tehrathum, the Federation of Community Forest Users of Nepal, the Department of Forest Research and Survey, the Central Bureau of Statistics and the Rural Reconstruction Nepal, Tehrathum.

Purposive sampling with $10 \%$ intensity i.e. 80 households incorporating different aspects of socio-economic condition especially the people including gender, ethnicity, education and geographic location were selected for the purpose of household survey. The ground-truth data were collected with the help of a GPS set. Data analysis was done using SPSS and MS Excel 2013 Packages while the Satellite image analysis was performed with the help of ArcGIS 10 and ERDAS IMAGINE 8.4 Softwares.

\section{Digital image processing and classification}

The study area was separated from the whole scene of the Landsat Satellite images of both 
the dates (1990 and 2013) using VDC shape file. The "extract by mask tool" of ArcGIS was used for this process to separate area of Interest (AOI) for the study. Ten training sites for each class were collected and merged to give the best representation of the class spectral reflectance. The ancillary data were converted from shape file format to Arc/Info format which is readable in remote sensing software. These files were then displayed over the Landsat scenes to aid in picking representative training sites.

Supervised classification with Maximum likelihood classifier was utilized for image classification and for the preparation of base maps for change detection (Lillesand et al., 2004). The data of different classification items (land use types) obtained from the field study were used as training samples for supervised classification of 2013 image and that of the topographical map were used for supervised classification of 1990 Image. The land use classes used for image classification were forest land, agriculture land, and others (grassland, rocks, settlement, and barren land and water bodies).

\section{Land use change detection}

The raster grids of 1990 and 2013 images were overlaid using "spatial analyst" of ArcGIS 10 Software. The land use changes in terms of areas were detected using the raster calculator. Finally, the areas converted from one class to another (class) were computed. The analysis and interpretation of different aspects of the numeric data of land use change were performed with the help of Microsoft Excel 2013.

\section{Social data analysis}

The analysis and interpretation of different aspects of the social data were performed using SPSS 14 and Microsoft Excel 2013.

\section{Results and discussion}

\section{Land use land cover change detection}

The classification of the Landsat TM 1990 Scene showed that forest was the major land use covering $1,066.23$ ha $(54 \%)$ followed by others (barren, settlement, grass, rock and water bodies) 457.83 ha (23\%) and agriculture 455.04 ha (23\%) in the study area (Fig. 2).

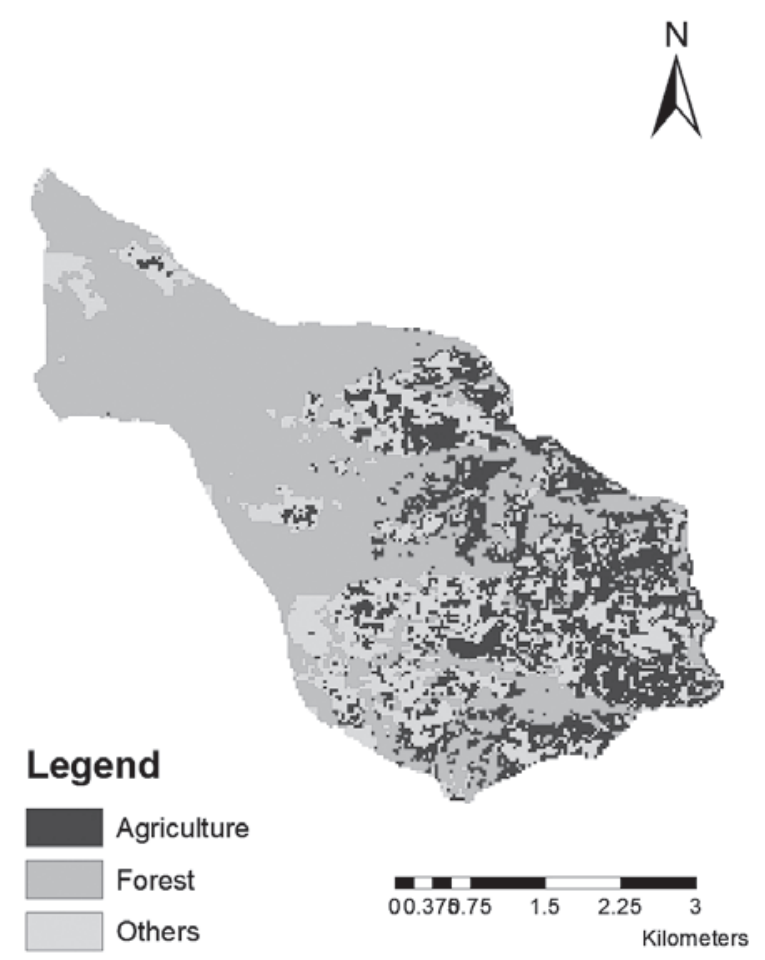

Fig. 2: Classified map of the study area in 1990

Similarly, the Landsat TM 2013 scene showed that forest was the major land use with 1,195.02 ha $(61 \%)$ followed by others 337.59 ha $(22 \%)$, and agriculture 443.61 ha (17\%) (Fig. 3).

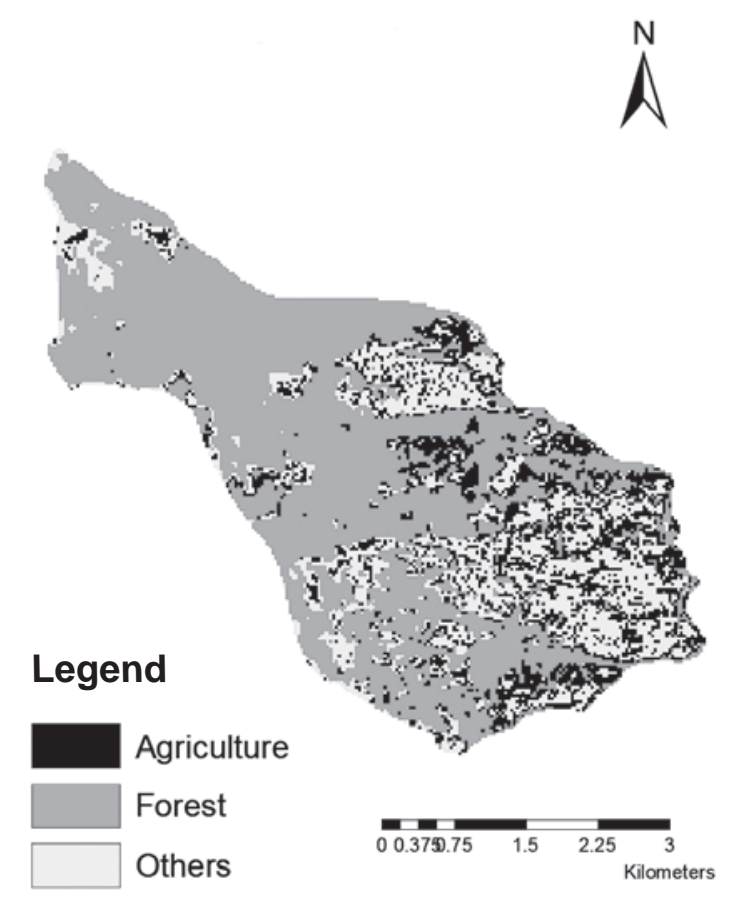

Fig. 3: Classified map of the study area in 2013

The study revealed that forest cover had increased whereas agriculture and others had decreased during the period of 23 years between 1990 
Table 1: Land use land cover change

\begin{tabular}{lrrrrrrrr}
\hline \multirow{2}{*}{$\begin{array}{l}\text { Land use/ } \\
\text { cover type }\end{array}$} & \multicolumn{2}{c}{ Landsat 1990 } & \multicolumn{2}{c}{ Landsat 2013} & \multicolumn{2}{c}{ Increase } & \multicolumn{2}{c}{ Decrease } \\
\cline { 2 - 9 } & Area (ha) & \% Cover & Area (ha) & \% Cover & Area (ha) & \% Cover & Area (ha) & \% Cover \\
\hline Forest & $1,066.23$ & 53.88 & $1,195.02$ & 60.47 & 128.79 & 6.6 & - & - \\
Agriculture & 455.04 & 22.99 & 337.59 & 17.08 & - & - & 117.45 & 5.91 \\
Others & 457.83 & 23.13 & 443.61 & 22.45 & - & - & 14.22 & 0.68 \\
\hline Total & $\mathbf{1 , 9 7 9 . 1 0}$ & $\mathbf{1 0 0 . 0 0}$ & $\mathbf{1 , 9 7 6 . 2 2}$ & $\mathbf{1 0 0 . 0 0}$ & $\mathbf{1 2 8 . 7 9}$ & $\mathbf{6 . 6}$ & $\mathbf{1 3 1 . 6 7}$ & $\mathbf{6 . 5 9}$ \\
\hline
\end{tabular}

and 2013. The change was found to be highest in forest, from $53.9 \%$ to $60.5 \%$, an increase by 6.6\% (Table 1). Gautam et al. (2002) and Balla et al. (2007) also observed similar results in their studies conducted at the Upper Rosi Watershed in the Middle Mountain region of Nepal and the Galaudu and Pokhare Khola watersheds in the Mid-hill region of Nepal, respectively. Agriculture was found to have decreased by $5.9 \%$, from $23.0 \%$ to $17.1 \%$. Similarly, others were found to have decreased by $0.6 \%$, from $23.1 \%$ to $22.5 \%$. The forests in the Middle Mountains are, in general, better managed and in many places forest cover have increased in recent years mainly due to the community forestry programme (Gautam et al., 2002; Niraula et al., 2013).

\section{Land use change map}

The Table 2 and Figure 4 below highlight the dynamics on land use change in the VDC within the period of 23 years. The agriculture cover was found to have decreased in the study area due to less favorable climatic condition and shortage of labor as most of the young people migrated to cities or foreign countries. This led people to shift the land use from agriculture to planting trees like Alnus nepalensis in private land, resulting increase in forest cover; this result corresponds with the previous studies. The National Biodiversity Strategy and Action Plan (2014-2020) states that private forest has increased throughout the country. Currently (as of August 18, 2013), there are 2,458 registered private forests in the country with a total of 3,329,885 trees grown in 2,361 ha of private land (MFSC, 2014).

Table 2: Dynamics on land use change between 1990 and 2013

\begin{tabular}{lrrrr}
\hline Land use & Forest & $\begin{array}{c}\text { Agri- } \\
\text { culture }\end{array}$ & Others & $\begin{array}{c}\text { Total, } \\
\mathbf{1 9 9 0}\end{array}$ \\
\hline Forest & 917.19 & 131.58 & 142.83 & $1,191.60$ \\
Agriculture & 75.69 & 155.07 & 105.21 & 335.97 \\
Others & 68.13 & 165.15 & 208.89 & 442.17 \\
\hline Total, 2013 & $\mathbf{1 0 6 1 . 0 1}$ & $\mathbf{4 5 1 . 8 0}$ & $\mathbf{4 5 6 . 9 3}$ & $\mathbf{1 , 9 6 9 . 7 4}$ \\
\hline
\end{tabular}

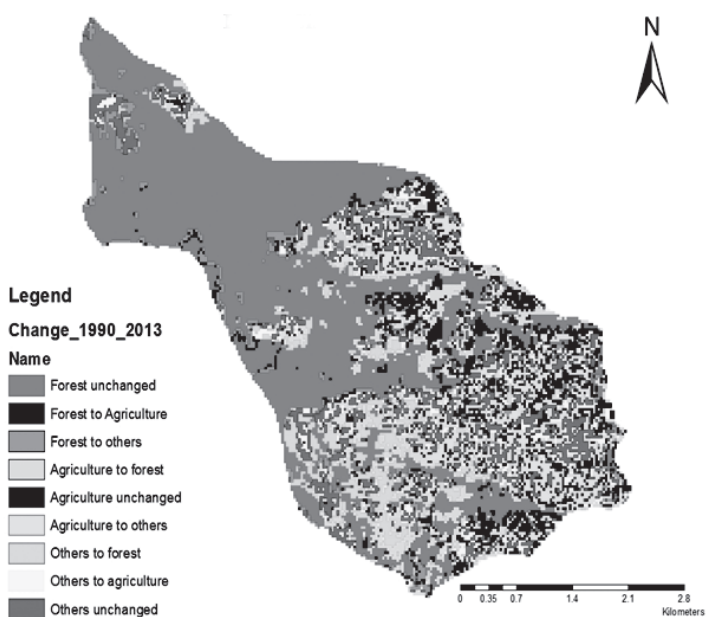

Fig. 4: The LULC change map of the study area between 1990 and 2013

The results in Table 3 below indicate that the performance of the classification methodology is quite good, reaching an overall accuracy of

Table 3: Accuracy assessment of classification

\begin{tabular}{lcccc}
\hline \multirow{2}{*}{ Classes } & \multicolumn{2}{c}{ Producer's accuracy } & \multicolumn{2}{c}{ User's accuracy } \\
\cline { 2 - 5 } & $\mathbf{1 9 9 0}$ & $\mathbf{2 0 1 3}$ & $\mathbf{1 9 9 0}$ & $\mathbf{2 0 1 3}$ \\
\hline Forest & 97.14 & 100.00 & 98.55 & 93.33 \\
Agriculture & 74.42 & 77.78 & 94.12 & 89.74 \\
Others & 93.48 & 90.24 & 76.79 & 86.05 \\
\hline
\end{tabular}


$89.94 \%$ and $90.14 \%$ for the 1990 and 2013 images respectively and overall Kappa statistics of 0.85 for both the Images. Both the accuracy assessments indicate high Cohen's Kappa values which are close to one (1). Considering the individual classification accuracies, the forest in 2013 was most accurately classified with $100 \%$ for producer's accuracy and $93.33 \%$ for user's accuracy. The higher accuracy of the maps could be possibly due to small study area as well as purposively selected smaller number of validation sites.

The forest cover in the study area was found to have increased annually at the rate of $0.5 \%$ during the period of 1990-2013 (Table 4). On the other hand, the agriculture land and the others lands were found to have gone down by $1.3 \%$ and $0.1 \%$ per annum.

Table 4: Rate of LULC change of the study area during the period of 1990-2013

\begin{tabular}{llc}
\hline S.N. & Land use/cover & Rate of change (\%) \\
\hline 1. & Forest & 0.50 \\
2. & Agriculture & -1.29 \\
3. & Others & -0.14 \\
\hline
\end{tabular}

Rate of Change $(\%)=\left(\left(a_{2} / a_{1}\right)^{(1 / n)}-1\right) \times 100$

(FAO, 2000),

Where, $\mathrm{a}_{2}=$ end-year data, $\mathrm{a}_{1}=$ base-year data and $\mathrm{n}=$ numbers of years.

\section{Social characteristics of the respondents}

Out of the 80 respondents, $60 \%$ respondents were male and $40 \%$ were female. The respondent's categories included the middle-aged (40-60 years) with $70 \%$ of the total sampled population followed by $15 \%$ young-aged (below 40 ) and $5 \%$ old-aged (over 60 years) belonging to all ethnic groups such as Limbu, Tamang, Gurung, Chhetri, Brahmin, Newar and Kami). The study was focused on the accumulation of past experience of almost 30 years back from the present, therefore the sampled population was rather purposive as the middle-aged category was focused.

The questionnaire survey revealed that $42.5 \%$ of the respondents were involved in farming (crop and livestock), $20 \%$ in business, $12.5 \%$ in wage labor and $7.5 \%$ involved in others; the rest $17.5 \%$ were found to be dependent upon remittance and pension (after retirement from service). Out of the total respondents, $62.5 \%$ were illiterate and only $37.5 \%$ were literate. Majority of the respondents (77.5\%) were dependent on fuel-wood while the rest $(22.5 \%)$ had used LPG as major sources of energy.

\section{Change in forest cover and its causes}

Majority of the respondents (90\%) believed that the forest cover was in increasing order in the VDC as compared to the previous decades. About $7.5 \%$ respondents felt that it was in decreasing order while the rest $(2.5 \%)$ believed that it was intact.

Majority of the respondents (52\%) believed that community forestry programme was the principal cause for the increase in forest cover. The community forestry programme has been generally successful in controlling or reversing the trends of deforestation and forest degradation in the Middle Mountains where 66.5 percent of Nepal's CFUGs are managing 910,379 ha (53.5\% of the total community forest area), whereas the programme is less successful in the Terai and High Mountain regions (MFSC, 2014).

About one third (28\%) of the respondents believed that the change in consumption pattern was responsible for the increase in forest cover. According to them, previously the local people had used forest as major source of fuel-wood and fodder, but now they had shifted their consumption pattern and had started growing trees on their own land mainly for producing and selling products like timber and NTFPs and secondly for producing fuel-wood and fodder for their household consumption. Some (13\%) of the respondents believed that awareness had helped in increasing the forest cover. Nowadays, people are more aware of the ecological and economical benefits that forests provide, and thus the activities that can damage forests are avoided by the local people.

A few $(7 \%)$ of the respondents believed that population growth (mainly due to influx of people from the higher parts to the lower of the VDC) had caused for decrease in the forest cover in some parts of the VDC. 


\section{Land use change and driving factors}

Majority $(75 \%)$ of the respondents claimed that the land use of the VDC was changing and the rest $(25 \%)$ of the respondents did not have any idea about it. Respondents were asked about the possible drivers responsible for causing the LULC change. The result showed that $55 \%$ of the respondents believed that migration from the VDC to city areas or abroad for several purposes had led to change in land use. Many youths had migrated to other areas so as to earn more money resulting in scarcity of working manpower in the village. So, most of the households changed their agricultural lands from cultivating agricultural crops to growing trees like Alnus nepalensis (Utis) and Cardamom (Alainchi) under the tree cover, resulting in the increase in the forest cover and decrease in the agriculture area within the VDC. A slightly more than half $(52 \%)$ of the respondents believed that infrastructure development like road was responsible for the change in the LULC of the VDC. Nearly half (45\%) of the people felt that policies like introduction of community forestry programme, energy-efficient stoves, stall feeding system and so on in the VDC were responsible for the change in the LULC. Similarly, almost half $(41 \%)$ of the respondents claimed that climate change was directly or indirectly responsible for the change in the LULC of the VDC while some $(10 \%)$ of the respondents believed that increase in population of the area was responsible for the change in the LULC of the VDC.

Analyzing the population of three decades, it was found that there had been decrease in the total population of the VDC in the recent years. Both the male and female populations had increased from 1981 to 2001, but the total population had decreased from 2001 to 2011 as there was decrease in the male population from 1,973 in 2001 to 1,681 in 2011 . It was verified by the local people that many young males had left the village in search of jobs and opportunities.

\section{Conclusion}

Out-migration, infrastructure development, climate change and policy are the major driving forces for the change in land use and land cover. However in the case of the Ambung VDC of Tehrathum district, the main reasons for the same were unfavorable climatic condition, drying of water resources and lack of labor owing to out- migration. During the period of 23 years (19902013), the land use of the Ambung VDC of Tehrathum district was found to have an increase of 128.8 ha $(6.6 \%)$ cover in forest cover but a decrease of 117.5 ha $(5.9 \%)$ in agriculture and 14.2 ha $(0.7 \%)$ in others (barren, settlement, grass, rock and water bodies). The results of the study showed that unfavorable climatic condition, drying of water resources and lack of labor owing to out-migration from the VDC resulted in diverting the local people of the VDC from agriculture to planting trees like $A$. nepalensis in their agriculture lands as well as in other lands within the VDC. The VDC was found to have a severe problem of rapid drying of water resources in spite of the increase in forest cover, and so research should be carried out to find out the reason and solve the problem before it is too late. Besides, the use of Remote Sensing and GIS should be increased and diversified for monitoring natural resources for better results and easy updates. Further, the local people especially the local youths should be provided with incomegenerating activities for their livelihood so as to retain them in their villages, which in turn might cease drastic land use changes in the rural areas causing adverse effects.

\section{Acknowledgements}

This paper is based on a part of the author's B.Sc. Forestry Thesis submitted to the Institute of Forestry, Pokhara Campus, Nepal. We are thankful to Rural Reconstruction Nepal/Multi Stakeholder Forestry Program (RRN/MSFP) and WWF, Nepal for providing Financial and technical support to conduct the study. We express our cordial thanks to Dr. Krishna Raj Tiwari, Mr. Yajna Prasad Timalsina, Mr. Navin Kumar Yadav for their critical suggestions during the study. Similarly DFO- Tehrathum, FECOFUN, Forest Action and RRN, Tehrathum and all the respondents of Ambung, Tehrathum are also duly acknowledged for their cooperation in accomplishing the study.

\section{References}

Agrawal, A. and Ostrom, E. 2001. Collective action, property rights, and decentralization in resource use in India and Nepal. Politics and Society 29 (4): 485-514.

Awasthi, K. D., Sitaula, B. K., Singh, B. R., Balla, M. K., Bajrachrya, R. M., and 
Dhoubhadel S. P. 2005. Analysis of land use structure in two mountain watershed of Nepal using FRAGSTATS. Forestry 13: 1-18.

Awasthi, K. D. 2004. Land Use Change Effects on Soil Degradation, Carbon and Nutrient Stock Sand Greenhouse Gas Emission in Mountain Watersheds. PhD Thesis, Agricultural University of Norway, Norway.

Awasthi, K. D., Sitaula, B. K., Singh, B. R. and Bajrachrya, R. M. 2002. Land-use change in two Nepalese watersheds: GIS and geomorphometric analysis. Land Degradation and Development 13: 495-513.

Balla, M. K., Awasthi, K. D., Singh, B. K. and Pradhan, B. M. 2007. Land use changes and geomorphometric analysis in Galaudu and Phokhare Khola watersheds in mid-hill region of Nepal. International Journal of Ecology and Environmental Sciences 33 (23): 171-182.

CBS. 2012. National Population and Housing Census 2011 (Village Development Committee/Municipality). Central Bureau of Statistics (CBS), Kathmandu, Nepal, 2.

DoF. 2005. Forest Cover Change Analysis of the Terai Districts (1990/91-2000/01). Department of Forests (DoF), Kathmandu, Nepal.

FAO. 2000. Global Forest Resources Assessment 2000. Food and Agriculture Organization of the United Nations, Rome, Italy.

FRA/DFRS. 2014. Terai Forests of Nepal (2010 - 2014). Forest Resource Assessment Nepal (FRA), Department of Forest Research and Survey (DFRS), Kathmandu, Nepal.
Gautam, A. P., Webb, E. L. and Eiumnoh, A., 2002. GIS assessment of land use-land cover changes associated with community forestry implementation in the Middle Hills of Nepal. Mountain Research and Development 22 (1): 63-69.

Gautam, A. P. 2007. Land Use Dynamics and Landscape Change Pattern in a Mountain Watershed in Nepal. http:// www.gisdevelopment.net/application/ environment/overview/envo $007 . \mathrm{htm}$ accessed on 18 Oct, 2014.

Lilisand, T. M. Kiefer, R. W. and Chipman, J. W. 2004. Remote Sensing and Image Interpretation. John Wiley and Sons, New York, USA.

MFSC. 2014. National Biodiversity Strategy and Action Plan (2014-2020). Government of Nepal, Ministry of Forests and Soil Conservation (MFSC), Kathmandu, Nepal.

Niraula, R. R., Gilani, H., Pokharel, B. K. and Qamen, F. M. 2013. Measuring impacts of community forestry programme through repeat photography and satellite remote sensing in Dolakha district of Nepal. Journal of Environment Management 126: 20-29.

Phong, L. T. 2004. Analysis of Forest Cover Dynamics and their Driving Forces in Bach Ma National Park and Buffer Zone using Remote Sensing and GIS. MSc Thesis submitted to the International Institute for Geo-information Sciences and Earth Observation, Enschede, The Netherlands.

UNEP. 2001. Nepal: State of the Environment 2001. United Nations Environment Program, Regional Resource Centre for Asia and the Pacific, Thailand. 